\title{
チーグラー・ナッ夕触媒
}

塩野毅

はじめに

遷移金属化合物之典型金属のアルキル，アリールあるい はヒドリド化合物からなる Ziegler-Natta 触媒は，エチレ ンの常圧高重合やプロピレンの立体特異性重合を進行させ るだけでなく，ブタジェンに代表される共役ジオレフィン の立体特異性重合や，ノルボルネンなどのシクロオレフィ ン類の開環メ夕セシス重合にあ有効であることから，現在 の高分子製造プロセスにおいて欠かすことのできない重要 な触媒となっている。本稿では，本特集の趣旨に従い，い かにして Ziegler, Natta 両教授がノーベル賞につながる 発見をなしえたのか，ノーベル賞受賞講演1 や関係者の文 献2),3)加らその経緯を振り返り，新たなブレークスルーへ の糧としたい。

\section{Ziegler の発見一ニッケル効果以前—}

Ziegler 触蝶発見の契機となった“ニッケル効果”は，あ まりにあ有名であるが，そこに至るまでには，30 年にわた る有機典型金属化学に関する权ばり強い研究といくつ汃の ブレークスルーが必要であった。Zeigler は Marburg/ Lahn 大学の Karl von Auwers 教授のもとで 1920 年に 学位取得後, 1923 年に講師となり「フリーラジカル理論」 を検証するための実験を始めた。その研究過程で, 有機ア ルカリ金属 $(\mathrm{Na}, \mathrm{K})$ の新しい合成法を見いだし，有機金属 の多様性に魅了され，その研究に傾注していった。1927 年には，これらの有機アルカリ金属が室温下でブタジェン やスチレンに容易に付加することを見いだし，この反応の 繰返し（後の “Aufbaureaktion”, 受賞講演では "stepwise organometallic synthesis”之称している) によりオリゴ マーや高分子量ポリマーが得られることを明らかにした。 ここで「高分子化学」を経験したことが後に大きく役立っ たとZiegler は述懐している。

1930 年にはブチルクロリドと金属リチウムからブチル リチウムを合成する方法を見いだした。ブチルリチウムを 蒸留により単離することを試みたが，ブテンと水素化りチ ウムが生成したことから，逆反応により有機りチウムを合 成する研究に没頭することになる。Ziegler は，1943 年に Max-Planck 石炭研究所に所長として招聘された後もエチ

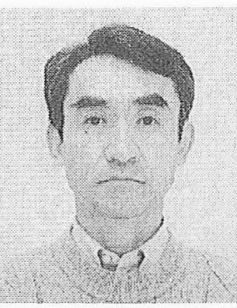

SHIONO, Takeshi 広島大学大学院工学研 究科 (739-8527 東広島市鏡山 1-4-1) ・教 授, 工学博士. 1983年 東京工業大学大学院 総合理工学研究科修士課程修了. 専門は高分 子化学, 触媒化学, とくに遷移金属触媒を用 いた高分子合成。

Ziegler-Natta Catalysts
レンと水素化リチウムとの反応を検討し続けたが成功せ ず，この研究を終了することを決定した。しかし，研究者 の一人が最後の実験として, 1947 年に報告されていた水 素化リチウムアルミニウムを用いたところ，エチレンから

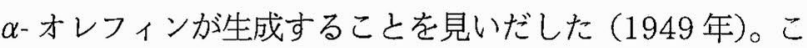
の実験結果に対する Ziegler の見解は，なぜ高価なリチウ ムを含まない水素化アルミニウムだけで実験を行わないの かというあのであった。こうして Ziegler は, 有機アルミ ニウムへのエチレンの挿入反応，いわゆる "Aufbaureaktion”を見いだすのである（式 1）。

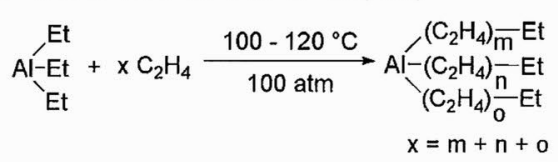

この反応で得られるポリエチレンの重合度はたかだか 100 程度であり，ポリマー之呼べるあのではなかった。だ が, Ziegler は逆にエチレンの反応量を抑え 6 8 量体の直 鎖トリアルキルアルミニウムを合成し，酸素酸化すること により直鎖高級アルコールを，温度を上げ $\beta$-水素脱離を起 こすことにより直鎖高級 $\alpha$-オレフィンを製造するプロセ スに展開した。また，金属アルミニウム，水素，オレフィ ンから有機アルミニウムを製造するプロセスを確立した。 ちなみに, トリメチルアルミニウムはこの方法で製造する ことができず，メチルアルミノキサンが高価である一因と なっている。

\section{Ziegler の発見一ニッケル効果以後一}

Ziegler の研究室ではステンレス製耐圧反応管を用いて “Aufbaureaktion”を研究していた。1953 年,トリプロピ ルアルミニウムへのエチレンの “Aufbaureaktion”を研究 していたとき，エチレン圧の降下は認められるのに目的と する重合体はまったく得られず, プロピレン, ブテンとト リエチルアルミニウムが生成していることがわかった。根 気強く原因を追及した結果, 反応管の洗浄を硝酸で行った 後に残留するニッケル塩がエチレンの選択的二量化を引き 起こしていることを突き止めた（式 2)。これがエチレン重 合触媒発見の契機となった。

$$
2 \mathrm{C}_{2} \mathrm{H}_{4} \stackrel{\mathrm{Ni} \text { 㙁 }+\mathrm{AlEt}_{3}}{\longrightarrow} \quad \mathrm{CH}_{2}=\mathrm{CH}_{-}-\mathrm{CH}_{2}-\mathrm{CH}_{3}
$$

エチレン重合触媒を求めて “Aufbaureaktion” への遷移 金属塩の添加効果を検討した結果, $\mathrm{Cr}$ 化合物で初めて重 合活性を見いだし，ついで $\mathrm{Zr}$ 化合物で一応の成功をみた。 そして, 常温・常圧でむ高活性を示す $\mathrm{TiCl}_{4}-\mathrm{AlEt}_{3}$ 系にた どり着いたのは 1953 年の末であった（式 3)。こうして穞 和な条件下で直鎖状の高密度ポリエチレンを与える触媒が 見いだされたのである。しかし，プロピレン重合に関して 
は $\mathrm{Zr}$ 化合物で検討したときにプロピレン圧の低下が観測 されないことから，研究者はプロピレンは重合しないと実 験ノートに記してしまった。プロピレンの炭化水素への溶 解度はエチレンの数倍あり, 液化圧す低く, プロピレンが 少々重合してあ圧変化は起こらないことを見落としていた のである。

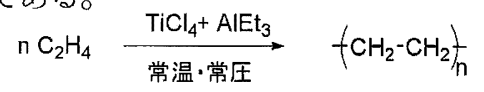

\section{Natta の研究}

Natta は 1924 年 Milan 工科大学の化学工学科を卒業 後, 1927 年に同校の教員資格試験に合格している。この 間に Brui 教授の下で研究生としてX 線結晶構造解析を化 学の諸問題に応用する研究を始め, Nattaは, これが立体 規則性ポリマーに関する一連の研究業績を上げるのに役 立ったと述べている。

当初, 低分子無機化合物の同形現象を研究していたが, 1932 年に Freiburg で Staudinger に合う機会を得て, 直 鎖高分子の研究に興味が移り，それらの格子構造を決定す るために電子線回折も応用し始めた。Nattaは, Pavia, Rome, Turin 各大学の教授を歴任中，これらの手法により 触媒や高分子の構造解析を行うとともに, メ夕ノール合 成, 不飽和化合物の水素化，オキソ法などの反応機構の解 明や触媒選択性の向上に成功している。1938 年より，化 学工業での経験を評価されて Milan 工科大学の所長に着 任し合成ゴムの生産に関する研究に着手, Ferraraにてブ タジェンースチレン共重合体生産プロセスを完成させた。 Natta はこの頃からオレフィン重合に関する研究を始めた と述べている。

"Aufbaureaktion”に興味をむったNatta は, Milan工 科大学のスポンサーである Montecatini 社と Zeigler の 間で結ばれた有機アルミニウムに関する研究のライセンス 契約に基づき， 3 人の化学者をZieglerの下に派遣した。 そして, 彼らの滞在中に上述のニッケル効果やエチレン重 合触媒の発見がなされたのである21,3)。

プロピレンは重合しないとの情報を得ていたにあかかわ らず, Montecatini 社加ら実用的な成果を求められていた Natta は, エチレン以外のモノマー, とくにプロピレンに 対象を絞り検討を開始し，1954 年 3 月にはポリプロピレ ンの合成に成功した。そして生成ポリマーが非晶性部分と 結晶性部分の混合物からなることに気づき, 溶媒分別で得 られた結晶性部分を X 線回折により調べることにより， 結晶性がポリプロピレンの規則的な構造（位置選択的に付 加しかつすべてのメチル基の配向が一定であること）に由 来することを明ら玑した。

さらにブタジェンの 1,2 -付加重合において， 2 種類の結 晶性ポリマーを合成単離することに成功し, 一方は, 結晶 性ポリプロピレンと同様に側鎖ビニル基の配向が同じであ るのに対し, 他方は交互に反対の配向を取っていることを 見いだした。Nattaはこれらのビニルポリマーの立体構造 を定義し, 語学に堪能な妻の助けを借りて, それぞれをギ リシャ語を用いて, イソタクチック (isotactic), シンジオ

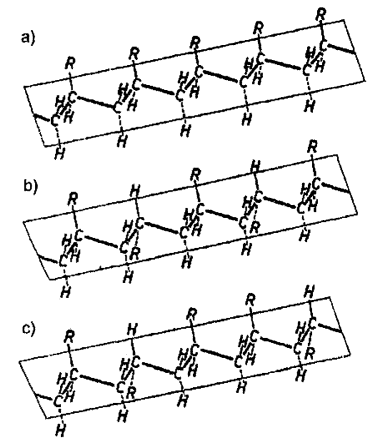

図 1 平面上に引き延ばした頭-尾結合ビニルポリマーの構造 a) isotactic, b) syndiotactic, c) atactic.

タクチック (syndiotactic), そして規則性のないむのをア タクチック (atactic) と命名した（図 1)。

\section{Zegler と Natta}

有機アルミニウムと遷移金属化合物からなる現在のオレ フィン重合触媒は，Ziegler の長年にわたる有機金属の基 礎研究の末にたどり着いた有機アルミニウムの化学の上に 成り立っていることは紛れあない事実である。しかし， Ziegler の研究の重要性をいち早く認識して情報収集に努 め, その触媒のあっとも重要な特質である立体特異性に気 づき基礎・応用両面で短期間に膨大な研究成果を上げた Nattaの貢献む大である。Zeigler は, この触媒を Mülheim 触媒と呼んでいたが，Nattaが Ziegler 触媒として 使用し名称が定着した。対照的な研究スタイルの両者であ るがここの二人なくしてこの触媒は語れない。ZeiglerNatta触媒と呼ばれる由縁である。

近年, 公立の研究機関や大学が独立行政法人化し, 産学 官連携が叫ばれ, 出口の明確な研究が中心となる傾向にあ る。次世代を切り開く新たな発見をするためには, Ziegler のノーベル賞受賞講演での言葉をかみしめるときかむしれ ない。

$「 1943$ 年に石炭研究所に招聘された時, 私は研究所の名 称が意味する目的に困惑した。不本意であ, 応用化学分野 の研究に方向転換しなければならないのだろうと考えた。 ルール地方ではコークス製造からエチレンが得られるた め，たとえば，新しいポリエチレン製造工程の研究がその ような研究課題に対応した。しかし，今日では確信してい る。当時む思っていたことだが, Mülheimにおいて, 最初 に設定した目標に向けて努力していたとしたら，私の創造 的活動の源泉は完全に干上がっていただろうと」。

\section{文献および注}

1) Ziegler, Natta のノーベル賞受賞講演ならびに経歴：http:// nobelprize.org/nobel_prizes/chemistry/laureates/1963/ index.html.

2) G. Wilke: "Karl Ziegler-The Last Alchemist," in "Ziegler Catalysts-Recent Scientific Innovations and Thechnological Improvements", G. Fink, R. Mulhaupt, H. H. Brintzinger, Eds., Springer-Verlag Berlin Hidelberg (1995) p. 1

3) Edward P. Moore Jr: ポリプロピレンハンドブック，佐久間 暢・保田哲男翻訳監修, 工業調査会 (1998) 